\title{
Association of VDR gene Apal polymorphism with obesity in Iranian population
}

Farzad Rashidi',2, Maryam Ostadsharif3,4

${ }^{1}$ Departamento de Immunología, Escuela de Medicina, Universidad Complutense, Madrid, España

${ }^{2}$ Young Researchers and Elite Club, Isfahan (Khorasgan) Branch, Islamic Azad University, Isfahan, Iran

${ }^{3}$ Department of Medical Basic Sciences, Isfahan (Khorasgan) Branch, Islamic Azad University, Isfahan, Iran

${ }^{4}$ Department of Medical Biotechnology, Isfahan (Khorasgan) Branch, Islamic Azad University, Isfahan, Iran

Introduction: Identifying obesity risk factors as a health problem facing communities is crucial given its complexity. The vitamin $\mathrm{D}$ receptor gene has been reported as a possible cause of this disease.

Objective: To study the association of the VDR gene Apal, Bsml, and Taql polymorphisms with obesity in an Iranian population.

Material and methods: We analyzed the genotypes of 348 obese $\left(B M I \geq 30 \mathrm{~kg} / \mathrm{m}^{2}\right)$ and 320 non-obese people (BMI: 18.5-24.9 kg/m²) using PCR-RFLP. We measured FBS, TG, total cholesterol, and HDL and LDL cholesterol levels in an automatic biochemical analyzer. Results: We found significantly higher BMI, FBS, and TG levels in the obese group compared to the control. In the obese individuals, the frequency of genotype AA was $47.1 \%$ and that of the combined $\mathrm{Aa}+\mathrm{aa}$ genotype, $52.9 \%$ while in the control group they were $30 \%$ and $70 \%$, respectively $(p=0.024,95 \%$ confidence interval $(\mathrm{Cl})=1.100-3.933$, odds ratio $(O R)=2.08$ ). A and a alleles frequencies for the Apal polymorphism were statistically significant in the two groups (allele A vs. $a ; p=0.017$ ). No significant relationship was observed between Taql genotypes and alleles in the control and obese subjects. Conclusion: We found that VDR Apal (rs7975232 C/A) polymorphism appeared to be a risk factor for obesity. Especially, the A allele and the AA genotype in Apal were associated with the obesity phenotypes.

Keywords: Obesity/genetic; vitamin D; polymorphism, genetic; body mass index; Iran.

Received: $14 / 11 / 2020$

Accepted: 18/06/2021

Published: $21 / 06 / 2021$

Citation:

Rashidi F, Ostadsharif M. Association of VDR gene Apal polymorphism with obesity in Iranian population. Biomédica. 2021:41:651-9.

https://doi.org/10.7705/biomedica.5898

Corresponding author:

Maryam Ostadsharif, Department of Medical Basic Sciences, Isfahan (Khorasgan) Branch, Islamic Azad University, University Blvd, Arqavanieh, Jey Street, Isfahan, Iran

Telephone: (+98) (313) 535 4058, mobile: (+98) (913) 303 1459; fax: (+98) (313) 5354060

maryam.ostadsharif@gmail.com; m.ostadsharif@ khuisf.ac.ir

\section{Author contributions:}

Maryam Ostadsharif conceived the study, analyzed the data and wrote the paper.

Farzad Rashidi conducted the experiments and analyzed the data.

\section{Funding:}

This project was funded by the Vice Chancellor for Research, Islamic Azad University, Isfahan (Khorasgan) Branch, Isfahan, Iran, under research code number 51751841001001.

\section{Conflicts of interest:}

The authors declare that there are no conflicts of interest regarding the publication of this paper.
Asociación del polimorfismo Apal del gen receptor de vitamina $D$ con la obesidad en una población iraní

Introducción. La determinación de los factores de riesgo de la obesidad en la población iraní como problema de salud de la comunidad es crucial dada su complejidad. El gen receptor de la vitamina $\mathrm{D}(V D R)$ se ha mencionado como posible causante de dicha enfermedad.

Objetivo. El objetivo del estudio fue investigar la asociación de los polimorfismos Apal, Bsml y Taql, con el gen VDR y la obesidad en una población iraní.

Materiales y métodos. Se analizaron genotipos de 348 individuos obesos (BMl $\left.\geq 30 \mathrm{~kg} / \mathrm{m}^{2}\right)$ y 320 no obesos (BMI: 18,5-24,9 kg/m²) mediante reacción en cadena de la polimerasa y polimorfismos de longitud de fragmentos de restricción (PCR-RFLP). Para medir los niveles de glucemia en ayunas, tiroglobulina (TG), colesterol total, colesterol HDL y colesterol LDL, se utilizó un analizador bioquímico automático.

Resultados. Los índices de masa corporal, glucemia en ayunas y TG fueron significantemente más elevados en el grupo de los obesos que en el de control. En los individuos obesos, la incidencia del genotipo AA fue de $47,1 \%$ y la del genotipo combinado Aa+aaa fue de $52,9 \%$, en tanto que en el grupo de control estas cifras fueron, respectivamente, de 30 y $70 \%\left(p=0,024 ; I_{95 \%}, 1,100-3,933\right.$; la razón de probabilidades (OR) fue de 2,08. La frecuencia de los alelos "A" y "a" para el polimorfismo Apal en ambos grupos fue estadísticamente significativa (alelo A Vs. A; $p=0,017$ ). No se observó ninguna relación significativa entre los genotipos Taql y los alelos en los sujetos obesos y, tampoco, en los controles.

Conclusión. El polimorfismo Apal del gen VDR (rs 7975232C/A) sería un factor de riesgo para la obesidad. El alelo y el genotipo AA en dicho polimorfismo se asociaron con los fenotipos de obesidad.

Palabras clave: obesidad/genética; vitamina D; polimorfismo genético; índice de masa corporal; Irán. 
Obesity is a complex disease influenced by environmental and genetic factors, which consists of the excessive accumulation of fats in adipose tissues as a result of an imbalance between energy consumption and intake. In the past 50 years, unhealthy habits in lifestyle have resulted in the so-called "obesogenic" environment, i.e., the intake of easily accessible energy-dense foods coupled with decreased physical activities. Researchers have suggested that genetic factors play a key role in regulating body weight (1). Obesity can cause many disorders, including cancer, cardiovascular disease, impaired glucose tolerance, hypertension, type 2 diabetes, sleep apnea, osteoarthritis, and gallbladder and liver disorders (2). The body mass index (BMI) has been commonly used as a surrogate marker of excessive body fats in the absence of accurate yet simple techniques for measuring them (3). Identifying the genetic factors contributing to the risk of obesity may help broaden the basic biological knowledge about the energy imbalance and determine the pathways and molecules that may be targeted for therapeutic purposes in humans.

Although vitamin D deficiency is a proven risk factor for obesity (4-6), the exact relationship between vitamin $\mathrm{D}$ status and obesity remains unclear. Vitamin $D$ function is induced by the attachment of 1,25-dihydroxyvitamin D3, one of vitamin $D$ active forms, to VDR as a nuclear receptor and a product of the VDR gene locus on chr12q13.1. A nuclear receptor acts as a ligandinducible transcription factor. Some polymorphisms reported in the VDR gene are associated with certain diseases and phenotypes (7). Several VDR gene polymorphisms, including Taql, Bsml, and Apal, are located near the $3^{\prime}$ un-translated region (UTR). In the human VDR, the Fokl translation-start site polymorphism was found in the 5' UTR.

In Iran, the prevalence of overweight/obesity is $63.6 \%$ in adults while that of abdominal obesity is $75.2 \%$, and it is higher in women $(32.2 \%)$ than in men (15.1\%) (8). Mirzazadeh, et al., have reported an obesity prevalence of $13.7 \%$ in men and $27.3 \%$ in women (9). Frequently, VDR gene polymorphisms have been found to be related to obesity, although these findings differ depending on the population (10-12). Considering them as risk factors for obesity, we studied three of these polymorphisms: Taql, Apal, and Bsml, and their relationships with serum factors in an obese Iranian population.

\section{Materials and methods}

\section{Data collection and participants}

We conducted a case-control study in the private nutrition clinic of Abolabbas, a charity institution in Khorasgan, Isfahan, Iran, from October, 2014, to March, 2015. Multiple clinical evaluations were performed and a questionnaire was completed by participants. The parameters recorded included weight, height, and BMI calculated by the accurate measurement of height (meters) and weight $(\mathrm{kg})$ under the supervision of a nutritionist. According to the BMI classification proposed by the World Health Organization (WHO), 320 subjects were categorized as healthy controls with normal weight (BMI: $18.5-24.9 \mathrm{~kg} / \mathrm{m}^{2}$ ) and no chronic diseases while 348 participants were considered obese individuals $\left(\mathrm{BMl} \geq 30 \mathrm{~kg} / \mathrm{m}^{2}\right)(13)$; their ages ranged from 25 to 80 years. Pregnant or breastfeeding women were excluded, as well as those with a family history of obesity, severe psychological disorders, or other serious diseases, and those consuming metformin, vitamin $D$, calcium supplements, or cholesterol-lowering medications. 
We used biochemical kits to evaluate fasting blood sugar (FBS) (Biorexfars, Iran), triglycerides (TG) (ParsAzmun, Iran), total cholesterol (ParsAzmun, Iran), high-density lipoprotein cholesterol (HDL cholesterol) (ParsAzmun, Iran), and low-density lipoprotein cholesterol (LDL cholesterol) (calculated parameter) after eight hours of nocturnal fasting. The results of tests related to blood biochemical parameters were evaluated by an internist and a nutritionist.

All the participants signed written informed consent forms before sampling and data collection. The Research Committee of the Isfahan (Khorasgan) Branch, Islamic Azad University, Isfahan, Iran approved the present study.

\section{Genotyping}

Blood samples were collected in EDTA tubes and DNA was extracted from peripheral blood leukocytes through standard salting-out. We used the PCRRFLP technique with forward and reverse primers to amplify and analyze the genomic DNA of VDR genotype Taql, Apal, and Bsml polymorphisms following the protocol of a previous study (14). Allelic nomenclatures of dominant (ABT) alleles are based on endonuclease success over its Taql, Apal, and Bsml restriction sites. Recessive (abt) alleles were therefore utilized when these endonucleases failed to cut their corresponding DNA molecules.

\section{Data analyses}

We analyzed the data using the SPSS-20.0 ${ }^{\mathrm{TM}}$ software. We examined the Hardy-Weinberg genotype equilibrium in the control group using the chisquared test. The descriptive data were expressed in means and standard deviations, as well as allele and genotype frequency. The KolmogorovSmirnov test was used to analyze the normality of distribution for each variable. To compare groups we used the chi-square test for qualitative data and for quantitative data, independent samples T-test. Odds ratios (OR) were calculated using logistic regression with $95 \%$ confidence intervals $(\mathrm{Cl})$. A p-value less than 0.05 was considered statistically significant.

\section{Results}

The characteristics of the obese and control subjects and the details of the control group (mean age: $50.02 \pm 12.47$ years) and the obese participants (mean age: $36.30 \pm 10.19$ years) are shown in table 1 . There were significantly more women in the obese group than in the control group. FBS, TG, and BMI were also significantly higher among the obese subjects compared to the controls. There were no significant differences between the two groups in terms of smoking status, alcohol consumption, HDL cholesterol, LDL cholesterol, total cholesterol, and heart disease; however, there were significantly more subjects who practiced physical activity in the control group than in the obese group $(p=0.010)$.

The Hardy-Weinberg equilibrium was observed in the Taql and Apal genotypes distributions in the control group ( $\mathrm{p}=0.086$ and 0.262 , respectively) (table 2). A significant deviation was, however, observed in the HardyWeinberg equilibrium of the Bsml polymorphism in the controls $(p<0.001)$. 
Table 1. Anthropometric and biochemical characteristics of study subjects

\begin{tabular}{|c|c|c|c|c|}
\hline Variable & & $\begin{array}{l}\text { Normal weight } \\
\text { (Control group } n=80 \text { ) }\end{array}$ & $\begin{array}{l}\text { Obese } \\
\text { (Case group } n=87 \text { ) }\end{array}$ & p-value \\
\hline \multirow[t]{2}{*}{ Sex; n (\%) } & Male & Sex; n (\%) & Sex; n (\%) & $0.002^{\mathrm{a}}$ \\
\hline & Female & & & \\
\hline \multirow[t]{2}{*}{ Smoking status; n (\%) } & Yes & Smoking status; n (\%) & Smoking status; n (\%) & $0.342^{\mathrm{a}}$ \\
\hline & No & & & \\
\hline \multirow[t]{2}{*}{ Physical activity; n (\%) } & Yes & Physical activity; n (\%) & Physical activity; n (\%) & $0.010^{a}$ \\
\hline & No & & & \\
\hline \multirow[t]{2}{*}{ Alcohol intake; n (\%) } & Yes & Alcohol intake; n (\%) & Alcohol intake; n (\%) & $0.428^{\mathrm{b}}$ \\
\hline & No & & & \\
\hline \multirow[t]{2}{*}{ Heart disease status; n (\%) } & Yes & Heart disease status; $\mathrm{n}(\%)$ & Heart disease status; n (\%) & $1.00^{\mathrm{b}}$ \\
\hline & No & & & \\
\hline Age (year) & Mean \pm SD & Age (year) & Age (year) & $<0.001^{c}$ \\
\hline BMI (kg/m2) & Mean \pm SD & BMl (kg/m2) & BMI (kg/m2) & $<0.001^{d}$ \\
\hline FBS (mg/dl) & Mean \pm SD & FBS (mg/dl) & FBS (mg/dl) & $<0.001^{c}$ \\
\hline LDL cholesterol (mg/dl) & Mean \pm SD & LDL cholesterol (mg/dl) & LDL cholesterol (mg/dl) & $0.244^{c}$ \\
\hline HDL cholesterol (mg/dl) & Mean \pm SD & HDL cholesterol (mg/dl) & HDL cholesterol (mg/dl) & $0.132^{\mathrm{c}}$ \\
\hline Triglycerides (mg/dl) & Mean \pm SD & Triglycerides (mg/dl) & Triglycerides (mg/dl) & $<0.001^{d}$ \\
\hline Total cholesterol $(\mathrm{mg} / \mathrm{dl})$ & Mean \pm SD & Total cholesterol (mg/dl) & Total cholesterol (mg/dl) & $0.071^{d}$ \\
\hline
\end{tabular}

p-values from a: Chi square test; b: Fisher exact test; c: Mann-Whitney test; $d$ : independent $t$ study

BMI: body mass index; FBS: fasting blood sugar; LDL: low-density lipoprotein; HDL: high-density lipoprotein

Table 2. Hardy-Weinberg equilibrium in the control group

\begin{tabular}{|c|c|c|c|c|c|}
\hline & Genotype & Observed & Expected & $\chi^{2}$ & $p$-value \\
\hline \multirow[t]{3}{*}{ Apal } & aa & 12 & 14.5 & 1.256 & 0.262 \\
\hline & $\mathrm{Aa}$ & 44 & 39.1 & & \\
\hline & $A A$ & 24 & 26.5 & & \\
\hline \multirow[t]{3}{*}{ Taql } & $\mathrm{tt}$ & 8 & 11.6 & 2.957 & 0.086 \\
\hline & $\mathrm{Tt}$ & 45 & 37.7 & & \\
\hline & TT & 27 & 30.6 & & \\
\hline \multirow[t]{3}{*}{ Bsml } & $\mathrm{bb}$ & 4 & 17.1 & 34.778 & $<0.001$ \\
\hline & $\mathrm{Bb}$ & 66 & 39.8 & & \\
\hline & BB & 10 & 23.1 & & \\
\hline
\end{tabular}

\section{VDR polymorphisms and obesity risk}

Table 3 shows the allelic and genotypic frequencies of VDR Apal and Taql polymorphisms in both groups. Apal and Taql genotypes were expressed as recessive homozygous (aa, tt), dominant homozygous (AA, TT), and heterozygous ( $\mathrm{Aa}, \mathrm{Tt})$. The frequency of genotype $\mathrm{AA}$ was $47.1 \%$ and that of the combined genotype Aa+aa, $52.9 \%$ in the obese group, figures that corresponded to $30 \%$ and $70 \%$ in the controls, were respectively $(p=0.024$, $\mathrm{OR}=2.08,95 \% \mathrm{Cl}=1.100-3.933$ ). Compared to genotype aa, Aa was found as a potential risk factor for obesity $(p=0.029, O R=3.417,95 \% \mathrm{Cl}=1.135-10.283)$. The frequencies of $A$ and a alleles in the Apal polymorphism were statistically significant in the two groups (allele A vs. $a, p=0.017$ ). As shown in table 3 , there was no significant association between Taql genotypes and alleles in neither group.

\section{Apal genotypes associations with biochemical parameters}

In table 4 we present the distribution of clinical variables by genotypes in the obese and control groups. We combined genotypes $\mathrm{Aa}$ and aa given the limited frequency of aa genotype in the VDR Apal polymorphism. Moreover, 
$86.2 \%$ of the $A A$ genotype and $70.6 \%$ of the $A a+$ aa group corresponded to women. According to the Chi-squared test, the two groups were significantly different in terms of gender distribution and the vast majority of the participants with genotype AA were female $(p=0.020)$.

As for the Apal variant, BMI $(p=0.022)$ and FBS $(p=0.003)$ were higher in the subjects carrying the AA genotype compared to those with the Aa+aa genotype. Other parameters such as heart disease, LDL cholesterol, HDL cholesterol, TG, and total cholesterol were not associated with the AA and $\mathrm{Aa}+\mathrm{aa}$ genotypes.

\section{Discussion}

A complex feedback mechanism mediated by receptors, enzymes, and hormones, regulates $1,25(\mathrm{OH})_{2} \mathrm{D}$. With a key function in bone and calcium homeostasis, $1,25(\mathrm{OH})_{2} \mathrm{D} / \mathrm{VDR}$ signaling can regulate proliferation, differentiation, and various cellular responses in the cardiovascular and immune systems $(15,16)$. The evidence suggests that VDR polymorphisms and vitamin $D$ deficiency can increase the risk of osteoporosis, calcium stones, diabetes, and prostate cancer (17) and the first may affect development and growth processes.

Table 3. Apal and Taql polymorphisms and obesity risk

\begin{tabular}{llllll}
\hline Genotype & Obese (\%) & Control (\%) & p-value & OR & 95\%Cl \\
\hline Apal & & & & \\
aa & $6(6.9)$ & $12(15.0)$ & & 1 & \\
Aa & $40(46.0)$ & $44(55.0)$ & 0.029 & 3.417 & $1.135-10.283$ \\
AA & $41(47.1)$ & $24(30.0)$ & 0.273 & 1.818 & $0.624-5.298$ \\
Aa+aa & $46(52.9)$ & $56(70.0)$ & & 1 & \\
AA & $41(47.1)$ & $24(30.0)$ & 0.024 & 2.08 & $1.100-3.933$ \\
a & $52(29.9)$ & $68(42.5)$ & & 1 & \\
A & $122(70.1)$ & $92(57.5)$ & 0.017 & 1.734 & $1.104-2.723$ \\
\hline Taql & & & & & \\
tt & $8(9.2)$ & $8(10.0)$ & & 1 & \\
Tt & $42(48.3)$ & $45(56.3)$ & 0.574 & 1.370 & $0.457-4.110$ \\
TT & $37(42.5)$ & $27(33.8)$ & 0.899 & 0.933 & $0.321-2.711$ \\
Tt+tt & $50(57.5)$ & $53(66.3)$ & & 1 & \\
TT & $37(42.5)$ & $27(33.8)$ & 0.245 & 1.453 & $0.775-2.724$ \\
t & $58(33.3)$ & $61(38.1)$ & & 1 & \\
T & $116(66.7)$ & $99(61.9)$ & 0.361 & 1.232 & $0.787-1.930$ \\
\hline
\end{tabular}

$P$-value, OR and $95 \% \mathrm{Cl}$ based on logistic regression

Table 4. Apal polymorphism and obesity components

\begin{tabular}{|c|c|c|c|c|}
\hline Variable & & $\begin{array}{l}\text { Apal } \\
\text { AA }\end{array}$ & $\begin{array}{c}\text { Apal } \\
\text { Aa+aa }\end{array}$ & p-value \\
\hline \multirow[t]{2}{*}{ Gender, n (\%) } & Male & $9(13.8)$ & $30(29.4)$ & \multirow[t]{2}{*}{$0.020^{\mathrm{a}}$} \\
\hline & Female & $56(86.2)$ & $72(70.6)$ & \\
\hline Heart disease, n (\%) & $\begin{array}{l}\text { Yes } \\
\text { No }\end{array}$ & $\begin{array}{c}3(4.6) \\
62(95.4)\end{array}$ & $\begin{array}{c}1(1.0) \\
101(99.0)\end{array}$ & $0.300^{b}$ \\
\hline BMI (kg/m2) & Mean \pm SD & $31.56 \pm 7.72$ & $28.55 \pm 6.62$ & $0.022^{c}$ \\
\hline FBS (mg/dl) & Mean \pm SD & $114.61 \pm 32.43$ & $103.69 \pm 29.41$ & $0.003^{c}$ \\
\hline LDL cholesterol (mg/dl) & Mean \pm SD & $107.71 \pm 37.16$ & $109.74 \pm 31.34$ & $0.718^{d}$ \\
\hline HDL cholesterol (mg/dl) & Mean \pm SD & $46.25 \pm 12.59$ & $45.33 \pm 10.65$ & $0.627^{d}$ \\
\hline Triglycerides (mg/dl) & Mean \pm SD & $162.98 \pm 86.38$ & $149.97 \pm 82.56$ & $0.242^{c}$ \\
\hline Total cholesterol (mg/dl) & Mean \pm SD & $184.29 \pm 45.25$ & $185.82 \pm 43.65$ & $0.832^{d}$ \\
\hline $\begin{array}{l}\text { value from a: Chi square } \\
\text { tudy }\end{array}$ & he Fich & Mn & hitnou & ependent \\
\hline
\end{tabular}


A large body of literature has been devoted to four common singlenucleotide polymorphisms in the VDR gene: Taql C>T (rs731236), Apal C>A (rs7975232), Fokl T>C (rs10735810), and Bsml A>G (rs1544410), whose relationships with different human diseases and traits have been explored (18). The single-nucleotide polymorphisms near the 3' UTR include Apal, Taql, and $B s m l$. Despite being non-functional, they are linked with a poly (A) microsatellite repeat in the 3' UTR, which can affect the stability of the VDR mRNA, the efficiency of protein translation, and the modulation of gene expression while the protein expression can be affected by altered intronic sequences $(7,19)$.

Our findings suggested an association between the VDR Apal polymorphism (rs7975232 C/A) and the susceptibility to obesity while the $\mathrm{A}$ allele and the AA genotype in Apal were associated with obesity phenotypes. The relationships of the VDR gene polymorphisms with the anthropometric and biochemical features of obesity were evident in the higher serum levels of FBS and BMI in genotype AA carriers.

Identifying the risk factors and genetic causes of obesity is crucial given its significant frequency in developing and developed countries. Risk factors are different in many populations and several VDR gene variants appear to affect obesity differently. A few studies suggest relationships between VDR polymorphisms and obesity $(11,20,21)$. For example, Ferrarezi, et al., found that $B s m l$ polymorphism was related to the height in a cohort of obese adolescents and children but Taql and Apal were not significantly associated with obese adolescents and children (22). In 2018, Correa-Rodríguez, et al., found that VDR genetic variants did not contribute to obesity phenotypes in a population of Caucasian young adults (23).

A study in Saudi Arabia reported vitamin D deficiency, VDR Bsml, and Taq1 genotypes as risk factors for obesity (24). In 2014, another study in Saudi Arabia by Al-Daghri, et al., revealed that polymorphisms affecting the vitamin D/VDR axis played a role in obesity in terms of the inflammation possibly caused by changes in microbial translocation and gut permeability. All the polymorphisms, namely Taql, Apal, and Bsml, were found to relate to obesity (20). In 2015, Ostadsharif, et al., obtained the frequency of alleles $F$ and $f$ in obese and healthy groups. The difference between the two alleles in the control and obese groups was significant $(p=0.005)$ and the individuals with the FF genotype in the control group had lower fasting blood sugar levels compared to the other genotypes (25). In contrast, a study in Poland reported no statistically significant differences in BMI, nor in the weight or height, for four VDR genotypes, i.e. Taql, Apal, Bsml, and Fokl (26).

The study of Apal and Taql to evaluate VDR polymorphisms in nephropathic and non-nephropathic patients with type 2 diabetes conducted by Iranian researchers did not show relationships between the Apal polymorphism and the nephropathic and non-nephropathic diabetic patients, although it showed significant differences in VDR gene Taql genotypes of diabetic patients with and without nephropathy (27).

The contribution of VDR gene polymorphisms to susceptibility to neurodegenerative diseases and conditions associated with calcium metabolism has been frequently reported in the literature. In Japan, the lumbar spine BMD of the common genotype AA was lower by $9.3 \%$ than in genotype aa in premenopausal women (28). In Greece, no heritability patterns were reported for the relation of genotype AA and low BMD (29). 
In Iran, Meamar, et al., evidenced that Fokl $\mathrm{f}$ and Apal a alleles significantly increase the risk of Parkinson's disease as was the case of Apal heterozygous genotype Aa compared to the AA homozygous (14).

In the present study, we found higher BMI and FBS levels in those subjects with genotype AA than in those with genotype Aa+aa. In a metaanalysis, the authors found significant relations between the VDR gene Taql, $B s m l, A p a l$, and Fokl polymorphisms and the risk of type 2 diabetes; Fokl polymorphism was a risk factor especially in Asians (30). On the other hand, studies in an Egyptian population showed differences in VDR genotypes Apa-I and Taq-I allele distribution and frequency between diabetic individuals and controls (31). There are, of course, a few studies demonstrating that the Apal polymorphism was related to obesity and blood glucose. Most articles focused on type 2 diabetes or polycystic ovary syndrome and other VDR gene polymorphisms $(21,32-36)$.

Given that the outcomes depend on numerous environmental, cultural, geographical, and socioeconomic factors, the results obtained differ by population. Like other studies, ours was not without limitations. The size of the study population and the fact that not all variants in the VDR gene were evaluated are the most important ones. Vitamin D serum levels were not assessed either. On the other hand, the most important strengths of the study were the ethnic homogeneity of participants and the association of genotype and blood biochemical factors with BMI.

We found relationships between the VDR gene Apal polymorphism and obesity in an Iranian population. The relation of Apal AA genotype and A allele to obesity phenotypes can make them obesity potential predictors. These findings suggest that the Apal polymorphism can predict the increased risk of obesity and help to identify novel treatment strategies for this metabolic disorder. We recommend future studies with larger samples to analyze the relationship between environmental factors and single nucleotide polymorphisms involved in obesity in different Iranian populations.

\section{References}

1. Walley AJ, Asher JE, Froguel P. The genetic contribution to non-syndromic human obesity. Nat Rev Genet. 2009;10:431-42. https://doi.org/10.1038/nrg2594

2. Kopelman P. Health risks associated with overweight and obesity. Obes Rev. 2007;8(Suppl.1):13-17. https://doi.org/10.1111//.1467-789X.2007.00311.X

3. World Health Organization W. Obesity: Preventing and managing the global epidemic. WHO Technical Report Series 894. 894th edition. Geneva: WHO; 2000.

4. Blum M, Dolnikowski G, Seyoum E, Harris SS, Booth SL, Petersonet J, et al. Vitamin D (3) in fat tissue. Endocrine. 2008;33:90-4. https://doi.org/10.1007/s12020-008-9051-4

5. Hypponen E, Power C. Vitamin D status and glucose homeostasis in the 1958 British birth cohort: The role of obesity. Diabetes Care. 2006;29:2244-6. https://doi.org/10.2337/dc06-0946

6. Wortsman J, Matsuoka LY, Chen TC, Lu Z, Holick MF. Decreased bioavailability of vitamin D in obesity. Am J Clin Nutr. 2000;72:690-3. https://doi.org/10.1093/ajcn/72.3.690

7. Uitterlinden AG, Fang Y, van Meurs JB, Pols HA, van Leeuwen JP. Genetics and biology of vitamin D receptor polymorphisms. Gene. 2004;338:143-56. https://doi.org/10.1016/i.gene.2004.05.014

8. Tabrizi JS, Sadeghi-Bazargani H, Farahbakhsh M, Nikniaz L, Nikniaz Z. Prevalence and associated factors of overweight or obesity and abdominal obesity in Iranian population: A population-based study of Northwestern Iran. Iran J Public Health. 2018;47:1583-92.

9. Mirzazadeh A, Sadeghirad B, Haghdoost AA, Bahreini F, Rezazadeh Kermani M. The prevalence of obesity in Iran in recent decade; a systematic review and meta-analysis study. Iran J Public Health. 2009; 38: 1-11. 
10. Faghfouri AH, Faghfuri E, Maleki V, Payahoo L, Balmoral A, Khaje Bishak Y. A comprehensive insight into the potential roles of VDR gene polymorphism in obesity: $A$ systematic review. Arch Physiol Biochem. 2020;1-13. https://doi.org/10.1080/13813455.2020.1788097

11. Vasilopoulos $\mathrm{Y}$, Sarafidou T, Kotsa K, Papadimitriou M, Goutzelas Y, Stamatis C, et al. VDR Taql is associated with obesity in the Greek population. Gene. 2013;512:237-9. https://doi.org/10.1016/j.gene.2012.10.044

12. Chen $X$, Wang W, Wang $Y$, Han $X$, Gao L. Vitamin D receptor polymorphisms associated with susceptibility to obesity: A meta-analysis. Med Sci Monit. 2019;25:8297-305. https://doi.org/10.12659/MSM.915678

13. World Health Organization. Obesity and overweight. 2013. Available from: https://www.who.int/ news-room/fact-sheets/detail/obesity-and-overweight

14. Meamar R, Javadirad SM, Chitsaz N, Asadian M, Kazemi M, Ostadsharif M. Vitamin $D$ receptor gene variants in Parkinson's disease patients. Egypt J Med Hum Genet. 2017;18:225-30. https://doi.org/10.1016/j.ejmhg.2016.08.004

15. Khammissa RA, Fourie J, Motswaledi MH, Ballyram R, Lemmer J, Feller L. The biological activities of vitamin $D$ and its receptor in relation to calcium and bone homeostasis, cancer, immune and cardiovascular systems, skin biology, and oral health. Biomed Res Int. 2018;2018. https://doi.org/10.1155/2018/9276380

16. Fleet JC. The role of vitamin $\mathrm{D}$ in the endocrinology controlling calcium homeostasis. Mol Cell Endocrinol. 2017;15:36-45. https://doi.org/10.1016/j.mce.2017.04.008

17. Bid HK, Mishra DK, Mittal RD. Vitamin-D receptor (VDR) gene (Fok-I, Taq-I and Apa-I) polymorphisms in healthy individuals from north Indian population. Asian Pac J Cancer Prev. 2005;6:147-52.

18. Zmuda JM, Cauley JA, Ferrell RE. Molecular epidemiology of vitamin D receptor gene variants. Epidemiol Rev. 2000;22:203-17. https://doi.org/10.1093/oxfordjournals.epirev.a018033

19. Ogunkolade BW, Boucher BJ, Prahl JM, Bustin SA, Burrin JM, Noonan K, et al. Vitamin $D$ receptor (VDR) mRNA and VDR protein levels in relation to vitamin $D$ status, insulin secretory capacity, and VDR genotype in Bangladeshi Asians. Diabetes. 2002;51:2294-300. https://doi.org/10.2337/diabetes.51.7.2294

20. Al-Daghri NM, Guerini FR, Al-Attas OS, Alokail MS, Alkharfy KM, et al. Vitamin D receptor gene polymorphisms are associated with obesity and inflammosome activity. PLoS ONE. 2014;9:e102141. https://doi.org/10.1371/journal.pone.0102141

21. Rahmadhani R, Zaharan NL, Mohamed Z, Moy FM, Jalaludin MY. The associations between VDR Bsml polymorphisms and risk of vitamin $\mathrm{D}$ deficiency, obesity and insulin resistance in adolescents residing in a tropical country. PLoS ONE. 2017;12:e0178695. https://doi.org/10.1371/journal.pone.0178695

22. Ferrarezi DAF, Bellili-Munoz N, Nicolau C, Cheurfa N, Guazzelli IC, Frazzatto E, et al. Allelic variations in the vitamin $D$ receptor gene, insulin secretion and parents' heights are independently associated with height in obese children and adolescents. Metabolism. 2012;61:1413-21. https://doi.org/10.1016/j.metabol.2012.03.018

23. Correa-Rodríguez M, Carrillo-Ávila JA, Schmidt-RioValle J, González-Jiménez E, Vargas S, Martín J, et al. Genetic association analysis of vitamin D receptor gene polymorphisms and obesity-related phenotypes. Gene. 2018;15:51-6. https://doi.org/10.1016/j.gene.2017.10.029

24. Al-Hazmi AS, Al-Mehmadi MM, Al-Bogami SM, Shami AA, Al-Askary AA, Alomery AM, et al. Vitamin $D$ receptor gene polymorphisms as a risk factor for obesity in Saudi men. Electronic Physician. 2017;9:5427-33. https://doi.org/10.19082/5427

25. Ostadsharif M, Rashidi-Khorasgani F. The relationship of Fokl polymorphism in vitamin $\mathrm{D}$ receptor (VDR) gene and obesity. J Isfahan Med Sch. 2015;33:350.

26. Jakubowska-Pietkiewicz E, Klich I, Fendler W, Mlynarski W, Chlebna-Sokol D. Effect of vitamin $\mathrm{D}$ receptor gene (VDR) polymorphism on body height in children-own experience. Postepy Hig Med Dosw (Online). 2013;67:873-8. https://doi.org/10.5604/17322693.1063747

27. Nosratabadi R, Arababadi MK, Salehabad VA, Shamsizadeh A, Mahmoodi M, Sayadi AR, et al. Polymorphisms within exon 9 but not intron 8 of the vitamin D receptor are associated with the nephropathic complication of type-2 diabetes. Int J Immunogenet. 2010;37:493-7. https://doi.org/10.1111/j.1744-313X.2010.00953.x 
28. Tokita A, Matsumoto H, Morrison NA, Tawa T, Miura Y, Fukamauchi K, et al. Vitamin D receptor alleles, bone mineral density and turnover in premenopausal Japanese women. $J$ Bone Miner Res. 1996;11:1003-9. https://doi.org/10.1002/jbmr.5650110718

29. Fountas L, Moutsatsou P, Kastanias I, Tamouridis N, Tzanela M, Anapliotou M, et al. The contribution of vitamin d receptor gene polymorphisms in osteoporosis and familial osteoporosis. Osteoporos Int. 1999;10:392-8. https://doi.org/10.1007/s001980050245

30. Li L, Wu B, Liu J-Y, Yang L-B. Vitamin D receptor gene polymorphisms and type 2 diabetes: A meta-analysis. Arch Med Res. 2013;44:235-41. https://doi.org/10.1016/j.arcmed.2013.02.00

31. Kamel MM, Fouad SA, Salaheldin O, Abd El-Razek AA, Abd El-Fatah Al. Impact of vitamin $D$ receptor gene polymorphisms in pathogenesis of type-1 diabetes mellitus. Int $\mathrm{J}$ Clin Exp Med. 2014;7:5505-10.

32. Fatma H, Abdul SN. Association of vVitamin D receptor gene Bsml polymorphism with type 2 diabetes mellitus in Pakistani population. Afri Health Sci. 2019;19 2164-71. https://doi.org/10.4314/ahs.v19i2.41

33. Sikander M. Relationship of Apal VDR gene polymorphism to type 2 diabetes mellitus in Pakistani population. Electronic J Biol. 2017;13:338-42.

34. Santos BR, Lecke SB, Spritzer PM. Apa-I polymorphism in VDR gene is related to metabolic syndrome in polycystic ovary syndrome: A cross-sectional study. Reprod Biol Endocrinol. 2018;16:38. https://doi.org/10.1186/s12958-018-0355-9

35. Angel $\mathrm{B}$, Lera $\mathrm{L}$, Márquez $\mathrm{C}$, Albala $\mathrm{C}$. The association of VDR polymorphisms and type 2 diabetes in older people living in community in Santiago de Chile. Nutr Diabetes. 2018;8:31. https://doi.org/10.1038/s41387-018-0038-9

36. Mohamed S, El-Askary A. Vitamin D receptor gene polymorphism among Egyptian obese children. Asian J Clin Nutr. 2017;9:24-9. https://doi.org/10.3923/ajen.2017.24.29 